TITLE:

\title{
Black spruce assimilates nitrate in boreal winter
}

$\operatorname{AUTHOR}(S):$

Koyama, Lina A; Kielland, Knut

CITATION:

Koyama, Lina A ... [et al]. Black spruce assimilates nitrate in boreal winter. Tree Physiology 2019, 39(4): 536-543

ISSUE DATE:

2019-04

URL:

http://hdl.handle.net/2433/241700

\section{RIGHT:}

This is a pre-copyedited, author-produced PDF of an article accepted for publication in 'Tree Physiology' following peer review. The version of record 'Lina A Koyama, Knut Kielland; Black spruce assimilates nitrate in boreal winter, Tree

Physiology, 39(4) 536-543' is available online at: https://doi.org/10.1093/treephys/tpy109.; The full-text file will be made open to the public on 21 November 2019 in accordance with publisher's 'Terms and Conditions for Self-Archiving'., この 論文は出版社版でありません。引用の際には出版社版をご確認ご利用ください。; This is not the published version.

Please cite only the published version. 
1 TITLE

Black spruce assimilates nitrate in boreal winter

\section{AUTHORS}

Lina A. Koyama ${ }^{1}$

Knut Kielland ${ }^{2}$

6 AFFILIATIONS AND ADDRESSES OF THE AUTHORS:

1. Graduate School of Informatics, Kyoto University

2. Institute of Arctic Biology, University of Alaska Fairbanks,

9 AUTHOR FOR CORRESPONDENCE:

Name: Lina A. Koyama

Address: Laboratory of Biosphere Informatics,

Department of Social Informatics, Kyoto 606-8501 Japan

E-mail: linak@bre.soc.i.kyoto-u.ac.jp

Phone number: $\quad+81-75-753-3297$

Fax number: $\quad+81-75-753-3133$

\section{RUNNING HEAD}




\section{ABSTRACT}

Winter has long been considered a dormant season in boreal forests regarding plant

23 physiological activity such as nutrient acquisition. However, biogeochemical data clearly show that

24 soil can remain unfrozen with substantial rates of nutrient transformation for several weeks

25 following autumn snowfall. Here we examined nitrate $\left(\mathrm{NO}_{3}^{-}-\mathrm{N}\right)$ assimilation by black spruce (Picea

26 mariana) during summer and winter in Interior Alaska to test our hypothesis that this boreal species

27 is able to assimilate $\mathrm{NO}_{3}{ }^{-} \mathrm{N}$, even at the very low temperatures typical of early winter. Nitrate

28 reductase activity (NRA) was measured in current year needles and fine roots of black spruce as an

29 indicator of $\mathrm{NO}_{3}{ }^{-} \mathrm{N}$ assimilation in the summer and winter at two boreal forest sites. $\mathrm{NO}_{3}{ }^{-} \mathrm{N}$

30 concentration in the needles and roots were also measured to determine whether $\mathrm{NO}_{3}{ }^{-} \mathrm{N}$ was

31 available in plant tissue for the enzyme. NRA and $\mathrm{NO}_{3}{ }^{-}-\mathrm{N}$ were detected in needles and roots in the

32 winter as well as the summer. The results of a generalized linear mixed model (GLMM) showed that

33 season had minimal effects on NRA and $\mathrm{NO}_{3}^{-}-\mathrm{N}$ concentration in this species. Additionally, the

34 effect of incubation temperature for the NRA assays was tested at $30{ }^{\circ} \mathrm{C}$ and $-3{ }^{\circ} \mathrm{C}$ for samples

35 collected in the winter. Substantial enzyme activity was detected in winter-collected samples, even

36 in incubations conducted at $-3{ }^{\circ} \mathrm{C}$. These results indicate that this dominant tree species in the boreal

37 forests of Interior Alaska, black spruce, has the capacity to assimilate $\mathrm{NO}_{3}^{-}-\mathrm{N}$ below freezing

38 temperatures, suggesting that the physiological activity required for $\mathrm{N}$ resource acquisition may

39 extend beyond the typical growing season. Our findings coupled to biogeochemical evidence for

40 high microbial activity under the snow also indicate that winter $\mathrm{N}$ acquisition should be taken into

41 account when estimating the annual $\mathrm{N}$ budgets of boreal forest ecosystems.

43 KEYWORDS

44 nitrate $\left(\mathrm{NO}_{3}^{-}-\mathrm{N}\right)$, nitrate reductase activity (NRA), non-growing seasons, Taiga 


\section{INTRODUCTION}

Nitrogen is among the most important limiting factors of plant productivity in the boreal

47 forests of Interior Alaska (Yarie and Van Cleve 2006). The annual plant $\mathrm{N}$ requirement is only partly

48 supplied by the major $\mathrm{N}$ source for plants, soil inorganic $\mathrm{N}$ (Valentine et al. 2006, Lisuzzo et al.

49 2008). In other words, there are marked discrepancies between the current estimates of inputs of

50 inorganic $\mathrm{N}$ available to plants (via $\mathrm{N}$-mineralization, $\mathrm{N}$-fixation, and dry/wet deposition) and their annual $\mathrm{N}$ uptake rates or requirements (Kielland 2001, Valentine et al. 2006, Lisuzzo et al. 2008).

The direct uptake of $\mathrm{N}$ in the form of amino acids further narrows the growing season gap between supply and demand (Persson and Näsholm 2001, Kielland et al. 2006a). Moreover, some of the discrepancies may be explained by uptake during the shoulder seasons, i.e., the period between growing season and mid winter, which has been largely ignored in the estimation of $\mathrm{N}$ flux including above-mentioned works. Kielland et al. (2006b) used over-winter incubations to demonstrate that boreal forest soils have a substantial capacity for $\mathrm{N}$ mineralization during the cold season and concluded that conventional measures have greatly underestimated the annual flux of inorganic $\mathrm{N}$ because they have been restricted to the growing season (May-September). In this study, we focused on $\mathrm{N}$ use by boreal plants during the winter to discuss the possible contribution of winter for $\mathrm{N}$ acquisition by plants. available to most plant species. $\mathrm{NO}_{3}{ }^{-} \mathrm{N}$ assimilation has been investigated in a variety of plant species using nitrate reductase activity (NRA) as an index (e.g., Smirnoff et al. 1984, Gebauer et al. 1988). Nitrate reductase (NR) catalyzes the reduction of $\mathrm{NO}_{3}{ }^{-}-\mathrm{N}$ to $\mathrm{NO}_{2}{ }^{-}-\mathrm{N}$, which is the first and rate-limiting step of plant $\mathrm{NO}_{3}{ }^{-}-\mathrm{N}$ assimilation. Measurements of NRA can be used to estimate plant

$67 \mathrm{NO}_{3}^{-}-\mathrm{N}$ use without disturbing the soil, which is not the case for experimental manipulations, such

68 as the application of ${ }^{15} \mathrm{~N}$ tracers. Numerous studies have shown that both external environmental

69 changes and internal physiological shifts in plants can cause temporal changes in $\mathrm{NO}_{3}{ }^{-}-\mathrm{N}$ assimilation (cf. Högberg et al. 1986, Gebauer et al. 1987, Schmidt et al. 1991, Högberg et al. 1992,

71 Stadler and Gebauer 1992, Ohlson and Högbom 1993, Pearson and Ji 1994, Troelstra et al. 1995,

72 Koyama et al. 2008). However, these studies measured NRA during the growing seasons of the 
species examined. NRA has rarely been examined in the winter, although Koyama et al. (2008) investigated the nitrate assimilation of a temperate, evergreen Quercus species during the winter, and the NRA of several evergreen coniferous species growing in temperate forests actually appears to be higher in the winter than in the summer (M. Ueda pers. comm.).

In boreal forests, where winter air temperatures can fall to below $-40{ }^{\circ} \mathrm{C}$, the seasonal patterns of enzyme activity may differ from warmer regions. On the other hand, Kielland et al. (2006b) demonstrated that soils from black spruce stands exhibited significant nitrification in late winter to spring. Hence, any potential to take up and/or assimilate $\mathrm{NO}_{3}{ }^{-}-\mathrm{N}$ at very low temperatures in boreal tree species will influence the current estimates of $\mathrm{N}$ flux in these cold, high latitude forests. Furthermore, recent global changes in climate could make uptake/assimilation activity during the winter of even greater relevance in nutrient budget calculations.

In this study, we compared winter and summer $\mathrm{NRA}$ and $\mathrm{NO}_{3}{ }^{-} \mathrm{N}$ concentrations in the needles and fine roots of black spruce (Picea mariana (Mill.) Britton, Sterns and Poggenb.) in a boreal forest located in Interior Alaska, USA. We also simulated ambient soil temperatures during wintertime enzyme incubations to determine the extent to which enzyme activity is maintained under near-natural conditions in an attempt to explore the idea that black spruce can maintain physiological activities at low temperatures.

\section{MATERIALS AND METHODS}

\section{Study Site}

The study was conducted in late-successional black spruce forests in Interior Alaska, USA $\left(64^{\circ} 52^{\prime} \mathrm{N}, 147^{\circ} 50^{\prime} \mathrm{W}\right)$. During the study years, the temperature at the nearby weather station ranged from $-39.13-33.02{ }^{\circ} \mathrm{C}$, averaging $0.37^{\circ} \mathrm{C}$ (Fig. 1; Van Cleve et al. 2016). The average annual precipitation at the site was $437 \mathrm{~mm}$, of which $35 \%$ fell as snow. The ground was covered with snow from mid-October through late April. The mean annual $\mathrm{NO}_{3}$ and total inorganic $\mathrm{N}$ deposition in this site from 2009 to 2016 were $0.54 \pm 0.10$ and $0.99 \pm 0.34 \mathrm{~kg}-\mathrm{N} \mathrm{ha}{ }^{-1}$, respectively, which are lower by an order of magnitude than the US average (National Atmospheric Deposition Program (NRSP-3) 2017; http://nadp.sws.uiuc.edu). 


\section{Sample Collection and Laboratory Analysis}

103 Experiment 1: effects of season, site, and tissue on $\mathrm{NRA}$ and $\mathrm{NO}_{3}^{-} \mathrm{-N}$ concentration two late-successional black spruce forests near the campus of the University of Alaska, Fairbanks, and two sites were located approximately $2 \mathrm{~km}$ away from each other (site $1: 64^{\circ} 51^{\prime} 36^{\prime \prime} \mathrm{N}$, $147^{\circ} 53^{\prime} 12^{\prime \prime} \mathrm{W}$ and site $\left.2: 64^{\circ} 51^{\prime} 49^{\prime \prime} \mathrm{N}, 147^{\circ} 50^{\prime} 43^{\prime \prime} \mathrm{W}\right)$. Plant sample collection was conducted at site

1081 in July (summer) and December (winter) in 2009 and at site 2 in July (summer) 2015 and

109 November (winter) 2016. At the time of summer sampling, the air temperatures in 2009 and 2015

110 were approximately $17{ }^{\circ} \mathrm{C}$ and $15^{\circ} \mathrm{C}$ and the surface soil temperatures were approximately $13{ }^{\circ} \mathrm{C}$

111 and $14{ }^{\circ} \mathrm{C}$, respectively. During winter sampling, the air temperatures were approximately $-20{ }^{\circ} \mathrm{C}$

112 and $-10{ }^{\circ} \mathrm{C}$ in 2009 and 2016 , and the surface soil temperatures were about $-2{ }^{\circ} \mathrm{C}$ and $-1{ }^{\circ} \mathrm{C}$,

113 respectively. The snow depth reached approximately $14 \mathrm{~cm}$ and $8 \mathrm{~cm}$ in 2009 and 2016,

114 respectively.

115 Current year needles and fine roots (diameter: $<2 \mathrm{~mm}$ ) of black spruce were collected in 116 the summer (July 2009 and 2015) and winter (December 2009 and November 2016) from five

117 mature trees. These needles and roots were used in NRA and $\mathrm{NO}_{3}{ }^{-}-\mathrm{N}$ concentration assays.

Experiment 2: effects of incubation temperature on NRA needle and root samples from site 1 were incubated at two temperatures: $30{ }^{\circ} \mathrm{C}$ and $-3{ }^{\circ} \mathrm{C}$. The incubation at $30{ }^{\circ} \mathrm{C}$ provided optimal conditions for enzymatic catalysis. Incubation at $-3{ }^{\circ} \mathrm{C}$ simulated the soil temperature on the day of sampling. We did not run tests at air temperature on the day of sampling $\left(-20^{\circ} \mathrm{C}\right)$ because this was well below the freezing temperature of the incubation buffers. 
$129 \mathrm{NRA}\left(-\mathrm{NO}_{3}\right) . \mathrm{NRA}\left(+\mathrm{NO}_{3}\right)$ is a measure of the nitrate reduction capacity with a non-limiting nitrate

130 supply; $\mathrm{NRA}\left(-\mathrm{NO}_{3}\right)$ is the nitrate reduction rate of nitrate absorbed by plants, which is considered to

131 be the closest approximation of the in situ $\mathrm{NO}_{3}{ }^{-}-\mathrm{N}$ assimilation rate (Thomas and Hilker, 2000).

132 Both NRA assays were conducted with modified versions of the Jaworski procedure (Jaworski, 1971,

133 Thomas and Hilker, 2000, Koyama and Kielland, 2011). NRA $\left(+\mathrm{NO}_{3}\right)$ was measured as the rate of

134 nitrite $\left(\mathrm{NO}_{2}^{-}-\mathrm{N}\right)$ production in an incubation buffer containing a non-limiting concentration of

$135 \mathrm{NO}_{3}^{-}-\mathrm{N} . \mathrm{NRA}\left(-\mathrm{NO}_{3}\right)$ was determined in parallel measurements using an incubation buffer without

136 additional $\mathrm{NO}_{3}{ }^{-} \mathrm{N}$, which allowed us to examine the relative magnitude of in situ $\mathrm{NO}_{3}{ }^{-} \mathrm{N}$

137 assimilation.

138 Current year needles and fine roots (diameter: $<2 \mathrm{~mm}$ ) were sampled from five mature

139 black spruce trees on each sampling occasion. Needle samples were collected from the surface of the

140 crown at various heights, and the sampled needles were mostly exposed to adequate light due to low

141 canopy density (Fujino pers. comm.). Root samples were washed in tap water and then in deionized

142 water to remove the soil. Fine root samples were randomly collected from root tips, thus possibly

143 ectomycorrhizal (ECM) fungal tissue were mixed with spruce root tissue. Approximately $100 \mathrm{mg}$

144 (fresh weight) of needles and roots were cut into small fragments (each ca. $2 \mathrm{~mm}$ long) and

145 transferred to test tubes. The incubation buffer $(5 \mathrm{~mL})$ was added to the needles and roots, and the

146 tube contents were vacuum infiltrated. The composition of the incubation buffer for $\mathrm{NRA}\left(+\mathrm{NO}_{3}\right)$

147 was as follows: $0.1 \mathrm{~mol} \mathrm{~L}^{-1} \mathrm{KNO}_{3}, 0.1 \mathrm{~mol} \mathrm{~L}^{-1} \mathrm{KH}_{2} \mathrm{PO}_{4}, 1.5 \%$ 1-propanol; the $\mathrm{pH}$ was adjusted to

$148 c a .7 .5$ using an $\mathrm{NaOH}$ solution. The concentration of $\mathrm{NO}_{3}^{-}-\mathrm{N}$ was determined by a preliminary

149 optimization process in which different concentrations of $\mathrm{NO}_{3}^{-}-\mathrm{N}$ were added to the incubation

150 buffer. A supply of varying $\mathrm{NO}_{3}{ }^{-}-\mathrm{N}$ concentration ranging from $0.00 \mathrm{mM}$ to $0.25 \mathrm{mM}$ in incubation

151 buffer yielded a peak of NRA at $0.10 \mathrm{mM}$ of $\mathrm{NO}_{3}{ }^{-}-\mathrm{N}$ supply (Appendix 1). The incubation buffer for

$152 \mathrm{NRA}\left(-\mathrm{NO}_{3}\right)$ contained all of the reagents other than $\mathrm{KNO}_{3}$. The samples were incubated for $1 \mathrm{~h}$ in

153 darkness, and $\mathrm{NO}_{2}^{-}-\mathrm{N}$ concentration in the incubation buffer was measured at the end point. Before

154 the measurement, enzyme activity was terminated by placing the sample vials in hot water $\left(>80^{\circ} \mathrm{C}\right)$.

155 The concentration of $\mathrm{NO}_{2}^{-}-\mathrm{N}$ in the incubation buffer was measured colorimetrically following

156 diazotization (Keeney and Nelson, 1982). The confounding effects of plant pigments were 
157 accounted for by subtracting the absorbance of controls to which N-naphthylethylene diamine

158 dihydrochloride was not added (Gebauer et al. 1998). A fraction of each leaf sample was oven-dried

159 at $105^{\circ} \mathrm{C}$ and then weighed to calculate the activity per unit dry weight.

$160 \quad$ For tissue $\mathrm{NO}_{3}{ }^{-} \mathrm{N}$ concentration measurements, the aliquots of needle and root samples

161 were dried and ground. Approximately $100 \mathrm{mg}$ of ground sample was extracted with $10 \mathrm{~mL}$

162 deionized water for $1 \mathrm{~h}$ at $45^{\circ} \mathrm{C}$. The extract was filtered, and the concentration of $\mathrm{NO}_{3}{ }^{-}-\mathrm{N}$ in the

163 extract was colorimetrically analyzed in an AutoAnalyzerIII (BLTec, Osaka, Japan). Plant pigments

164 in extracts might cause an overestimation of $\mathrm{NO}_{3}{ }^{-} \mathrm{N}$ concentration, and other unknown compounds

165 in the extracts might inhibit the reduction of $\mathrm{NO}_{3}{ }^{-} \mathrm{N}$ to $\mathrm{NO}_{2}^{-}-\mathrm{N}$, which is colorimetrically measured

166 in the AutoAnalyzerIII (data not shown). Again, the confounding effects of plant pigments were

167 taken into account by subtracting the absorbance of controls to which N-naphthylethylene diamine

168 dihydrochloride was not added. In addition, a standard addition method was applied to compensate

169 for the effects of pigments and other compounds in the extract as necessary when the sample

170 composition was unknown or complex and might affect the analytical signal (Harris 2007). In this

171 method, standard solutions of known concentrations were added to each extract, and from the

172 increases in signal (i.e., absorbance), the concentration in the original extract was calculated.

174 Statistical Analysis

For experiment 1 , we fitted a generalized linear mixed model (GLMM) with a gamma

176 distribution to evaluate the effects of Season (summer or winter), Site (site 1 or site 2), and Tissue

177 (needle or root) on $\mathrm{NRA}\left(+\mathrm{NO}_{3}\right), \mathrm{NRA}\left(-\mathrm{NO}_{3}\right)$, or $\mathrm{NO}_{3}$ concentrations, following a Shapiro-Wilk test

178 to test the normality of data. Five individual trees were included as random effects. Two of

$179 \mathrm{NRA}\left(+\mathrm{NO}_{3}\right)$ and seven of $\mathrm{NO}_{3}$ concentrations data were below the detection limit; to fit the model

180 with a gamma distribution, $1 \times 10^{-10}$ and $1 \times 10^{-6}$ were substituted for zero for these samples that

181 presented values below the detection limit, respectively. All possible subsets of the explanatory

182 variables and their interactions were compared with Akaike Information Criterion (AIC) for each of

183 the response variables, $\mathrm{NRA}\left(+\mathrm{NO}_{3}\right), \mathrm{NRA}\left(-\mathrm{NO}_{3}\right)$, or $\mathrm{NO}_{3}{ }^{-}-\mathrm{N}$ concentrations. 
185 distribution to evaluate effects of the variables Incubation temperature $\left(-3{ }^{\circ} \mathrm{C}\right.$ or $\left.30{ }^{\circ} \mathrm{C}\right)$ and Tissue

186 (needle or root) on $\mathrm{NRA}\left(+\mathrm{NO}_{3}\right)$ or $\mathrm{NRA}\left(-\mathrm{NO}_{3}\right)$. Five individual trees were included as random

187 effects. All possible subsets of the explanatory variables and their interactions were compared with

188 Akaike Information Criterion (AIC) for each of response variable, $\mathrm{NRA}\left(+\mathrm{NO}_{3}\right)$ or $\mathrm{NRA}\left(-\mathrm{NO}_{3}\right)$.

189 It should be noted that in both experiments, the link function 'inverse' was applied for

190 GLMM with gamma distribution, and consequently a positive value of the coefficient implies a

191 negative effect of the explanatory variable on the response variable. It is worth noting that all of the

192 regression coefficients can be compared to each other, although they were not standardized, as all of

193 the variables are categorical variables with an equal number of categories: two in each experiment.

194 All statistical analyses were conducted using the statistical platform R (ver. 3.3.3;

195 http://www.R-project.org), and the lme4 package (version 1.1-13) was used for fitting GLMM.

RESULTS

Experiment 1: effects of season, site, and tissue on $\mathrm{NRA}$ and $\mathrm{NO}_{3}^{-}-\mathrm{N}$ concentration

Both NRA $\left(+\mathrm{NO}_{3}\right)$ and $\mathrm{NRA}\left(-\mathrm{NO}_{3}\right)$ were detected in the needles and fine roots of black spruce in experiment 1 (Fig. 2a, b). The best performing model fitted for $\mathrm{NRA}\left(+\mathrm{NO}_{3}\right)$ had Season,

201 Site, and their interaction as explanatory variables. However, only Site had the coefficient with a

202 P-value lower than 0.05 , indicating that zero was not included within the $95 \%$ Wald confidence

203 interval (CI) of estimated coefficient (Table 1). The best performing model fitted for $\mathrm{NRA}\left(-\mathrm{NO}_{3}\right)$

204 had all of the explanatory variables and their interactions except the interaction of Season $\times$ Site $\times$

205 Tissue. However, the coefficient for the Season and the interaction Season $\times$ Tissue exhibited

206 P-values higher than 0.05 , indicating that zero was included within the $95 \%$ Wald CI of estimated 207 coefficients.

$\mathrm{NO}_{3}{ }^{-}-\mathrm{N}$ was also detected in most needle and fine root samples (Fig. 2c). The best

209 performing model fitted for $\mathrm{NO}_{3}{ }^{-}-\mathrm{N}$ concentration had Season, Tissue, and their interaction as

210 explanatory variables. However, Season and Tissue had a P-value higher than 0.05 , indicating that 211 zero was included within the $95 \%$ Wald CI of estimated coefficients. 


\section{Experiment 2: effects of incubation temperature on NRA}

Both $\mathrm{NRA}\left(+\mathrm{NO}_{3}\right)$ and $\mathrm{NRA}\left(-\mathrm{NO}_{3}\right)$ were detected in current year needles and fine roots,

215 even at the low incubation temperature $\left(-3^{\circ} \mathrm{C}\right.$; Fig. 3). Both the Incubation temperature and Tissue

216 were selected for the best performing model fitted for $\mathrm{NRA}\left(+\mathrm{NO}_{3}\right)$, but their interaction was not

217 (Table 2). Moreover, both the coefficient for the Incubation temperature and Tissue showed P-values

218 lower than 0.05 , indicating that zero was not included within the $95 \%$ Wald CI of estimated

219 coefficient. On the other hand, the best performing model for $\mathrm{NRA}\left(-\mathrm{NO}_{3}\right)$ had only Incubation

220 temperature as a coefficient, and the P-value for that was higher than 0.05 , indicating that zero was

221 included within the $95 \%$ Wald CI of estimated coefficient.

\section{DISCUSSION}

\section{Nitrate Assimilation of Black Spruce in Winter and Summer}

Winter is generally considered to be a season of dormancy in boreal forests due to the

extremely low temperatures, reduced light intensity, and short photoperiods. However, we have

demonstrated that black spruce trees in Interior Alaska are able to assimilate $\mathrm{NO}_{3}{ }^{-}-\mathrm{N}$ in the winter as well as in the summer (Fig. 2), indicating that, in the winter, (i) black spruce induced NR and (ii) $\mathrm{NO}_{3}{ }^{-}-\mathrm{N}$ was available for $\mathrm{NR}$.

The disparity between our findings and the accepted winter dormancy concept could be attributed to a de novo induction of the enzyme during the storage time in our experiments. However, the in vivo NRA was measured under the premise that NR had not been induced de novo during the storage period after sample collection. This premise was based on the known light requirement for

234 NR induction (Lillo et al. 2004); our samples were stored in complete darkness. Furthermore,

235 Högberg et al. (1986) found that the shoot NRA of Deschampsia flexuosa declined for the first 30

236 min of storage and remained stable thereafter. Thus, we suggest that NR was not newly induced in

237 our detached samples during storage, and that the NRA detected by our measurements was not likely

238 to be the result of artificially inflated rates of enzyme induction following sample collection. 
241 between Season $\times$ Site were selected as effective variables in the best models for both of

$242 \mathrm{NRA}\left(+\mathrm{NO}_{3}\right)$ and $\mathrm{NRA}\left(-\mathrm{NO}_{3}\right)($ Table 1$)$. In addition, Tissue and the interaction between Site $\times$

243 Tissue were also selected in the best model for $\mathrm{NRA}\left(-\mathrm{NO}_{3}\right)$. On the other hand, only the interaction

244 between Season $\times$ Tissue was selected as a variable influencing $\mathrm{NO}_{3}^{-}-\mathrm{N}$ concentration. Taken

245 together, these results indicated that season was not a significant factor affecting $\mathrm{NO}_{3}{ }^{-}-\mathrm{N}$ use by

246 black spruce. Because newly expanding leaves contain higher concentrations of $\mathrm{N}$ than fully

247 expanded leaves, winter buds of temperate evergreen species most likely receive $\mathrm{N}$ transported from

248 old tissues (Silla and Escudero 2003, Koyama et al. 2008). Consequently, we surmise that the

249 wintertime acquisition of $\mathrm{N}$ by the needles of black spruce may play a role in the preparation of

250 additional $\mathrm{N}$ sources for the new needles that flush in late spring in these sites.

Lambers et al. (2008) demonstrated that the NRA shoot/root ratio generally increases with

$\mathrm{NO}_{3}{ }^{-}-\mathrm{N}$ availability in temperate and subtropical species. Our results showed that black spruce

assimilate nitrate in their current year needles. Some previous studies revealed prior assimilation of nitrate in the roots of coniferous species (Peuke and Tischner 1991, Gebauer and Schulze 1997, Yao et al. 2011), and our results were contrary to these observations. Assuming soil $\mathrm{NO}_{3}{ }^{-}-\mathrm{N}$ availability was lower at site 2 based on the site differences of NRAs, the results were consistent with the relationship between the allocation of NRA and soil $\mathrm{NO}_{3}{ }^{-}-\mathrm{N}$ availability in temperate and subtropical species (Lambers et al. 2008), because both $\mathrm{NRA}\left(+\mathrm{NO}_{3}\right)$ and $\mathrm{NRA}\left(-\mathrm{NO}_{3}\right)$ were higher in roots than in needles at site 2 .

\section{Effects of Incubation Temperature on Winter NRA}

$\mathrm{NRA}\left(+\mathrm{NO}_{3}\right)$ was detected even at the low incubation temperature, $-3{ }^{\circ} \mathrm{C}$, both in needles and roots (Fig. 3), although the low incubation temperature significantly reduced the activity in comparison with the samples incubated at the high temperature $\left(30^{\circ} \mathrm{C}\right.$; Table 2$)$. Roots showed lower $\mathrm{NRA}\left(+\mathrm{NO}_{3}\right)$ than needles, and this allocation pattern did not differ by the incubation

266 temperature. On the other hand, neither incubation temperature nor tissue influenced $\mathrm{NRA}\left(-\mathrm{NO}_{3}\right)$,

267 implying the low incubation temperature did not inhibit $\mathrm{NRA}\left(-\mathrm{NO}_{3}\right)$. Thus, the enzyme in winter 268 needles is clearly capable of catalyzing $\mathrm{NO}_{3}{ }^{-} \mathrm{N}$ reduction at very low temperatures. 
270 (Nicholas et al. 1976, Al Ghabi and Hipkin 1984, Gebauer et al. 1984). Optimal temperatures were

271 found to be in the range $28-33{ }^{\circ} \mathrm{C}$ (Sym, 1984, Högberg et al. 1992), and even higher optimal

272 temperatures $\left(40-50{ }^{\circ} \mathrm{C}\right)$ were reported for some crop species (Chopra, 1983). Högberg et al

showed that NRA increased with temperature, reaching an optimum at approximately $25^{\circ} \mathrm{C}$. At the

coldest incubation temperature they applied (approximately $0{ }^{\circ} \mathrm{C}$ ), the NRA was very low (Högberg et al. 1992). However, these results were obtained from temperate species and/or herbaceous taxa, such as barley (Hordeum vulgare) and D.flexuosa. No trials were conducted on boreal evergreen tree species. Furthermore, earlier experiments were conducted during the growing season, but never in winter. The distinct NR responses to temperature in boreal species may well represent an adaptation to cold climates.

We tested only two temperatures in our study, which did not allow us to examine the functional responses of the NR enzyme to temperature. We were also unable to measure enzyme activity in the needle samples at ambient winter air temperatures $\left(-20^{\circ} \mathrm{C}\right)$, which would have frozen the incubation buffer. Accordingly, we cannot rule out the possibility that we overestimated the activity of the enzyme in winter needle samples. Nevertheless, our study has reduced the level of NRA overestimation attributable to the conventional incubation temperature $\left(30^{\circ} \mathrm{C}\right)$.

\section{Ecological Implications}

Based on the results showing the capacity of black spruce to use $\mathrm{NO}_{3}{ }^{-} \mathrm{N}$, we conclude that this species is able to assimilate $\mathrm{NO}_{3}{ }^{-} \mathrm{N}$ in the winter. In earlier studies that showed significant species difference in the capacity to assimilate nitrate, coniferous species or gymnosperms were considered to have low capacities for nitrate assimilation (Smirnoff et al. 1984, Gebauer et al. 1998, Hayashi-Tang et al. 2012), and the our results were consistent with these earlier studies. However, considering that black spruce maintained the capacity to assimilate nitrate in winter, this observation

294 indicates that they are capable of using nitrate for a longer period than deciduous species. 
297 possible that the plants had absorbed and stored $\mathrm{NO}_{3}{ }^{-}-\mathrm{N}$ during previous seasons and then

298 subsequently assimilated the stored ions during the following winters. Our results showed lower root

$299 \mathrm{NO}_{3}^{-}-\mathrm{N}$ concentration in the winter than in the summer (Fig. 2c), and this may be a consequence of

300 plant usage of internally stored $\mathrm{NO}_{3}$ in winter. The quantitative evaluation of winter $\mathrm{N}$ acquisition to

301 the whole $\mathrm{N}$ budget requires further investigation.

Kielland et al. (2006b) suggested that the restriction of soil process measurements to the

303 growing season greatly underestimated the annual flux of soil $\mathrm{N}$ in Interior Alaska. Our data

304 corroborate this viewpoint; the $\mathrm{N}$ assimilation that we measured during the winter strongly indicated

305 that the annual $\mathrm{N}$ budgets of boreal ecosystems should be reexamined.

The assimilation of $\mathrm{NO}_{3}{ }^{-}-\mathrm{N}$ is an energy consuming process (Bloom et al. 1992). When

excess light energy is available beyond that required for carbon assimilation, it may be used for

$\mathrm{NO}_{3}^{-}-\mathrm{N}$ assimilation, thereby reducing the damaging effects of photoinhibition. The putative winter

$309 \mathrm{NO}_{3}^{-}-\mathrm{N}$ assimilation of boreal black spruce may function as a sink for the surplus light energy

310 absorbed by photosynthetic pigments. This proposal is certainly worthy of further exploration,

311 especially considering climate change may alter the relationship between temperature and light

312 condition.

313 New information on plant physiological performance during winter, such as photosynthesis

314 (Miyazawa and Kikuzawa 2004, Saarinen et al. 2016) and N use (Koyama et al. 2008, Onipchenko

315 et al. 2009, Ueda et al. 2010) is relevant to current considerations of recent climate change (Makoto

316 et al. 2014, Sanders-Demott and Templer 2017). The effects have generally been considered in terms

317 of the direct influence of higher temperatures, changes in habitat availability, and extensions of plant

318 growth periods (Walther et al. 2002, Cleland et al. 2007, Bokhorst et al. 2008, Miller-Rushing and

319 Primack 2008, Polgar and Primack 2011). With the current lack of information on the responses of

320 plant NRA to the range of temperatures during the boreal winter, we are not in a position to estimate

321 the influence of shorter and warmer winters on plant $\mathrm{N}$ acquisition. However, our data clearly show

322 that the influence of a changing winter climate on ecosystem $\mathrm{N}$ budgets should be taken into account

323 in considerations of the effects of climate warming. 


\section{FUNDING}

326 This research was partly supported by a Grant-in-Aid for Young Scientists (B) from the

327 Japan Society for the Promotion of Science (No. 21780149) and a Grant-in-Aid for Young Scientists

328 (A) from the Japan Society for the Promotion of Science (No. 25712017) awarded to LAK.

\section{ACKNOWLEDGEMENTS}

We would like to thank Drs. N. Tokuchi and M. Ueda for inspiring us to conduct this study.

332 We would also like to thank Mr. K. Olson and Ms. Audrey Mutschlecner for their assistance with

333 our field and laboratory work. 


\section{REFERENCES}

335 Al Gharbi A, Hipkin CR (1984) Studies on nitrate reductase in British angiosperms I. A comparison of nitrate reductase activity in ruderal, woodland-edge and woody species. New Phytol 97:629-639.

Bloom AJ, Sukrapanna SS, Warner RL (1992) Root respiration associated with ammonium and nitrate absorption and assimilation by barley. Plant Physiol. 99:1294-1301.

Bokhorst S, Bjerke J, Bowles F, Melillo J, Callaghan T, Phoenix G (2008) Impacts of extreme winter warming in the sub-Arctic: growing season responses of dwarf shrub heathland. Global Change Biol. 14:2603-2612.

Chopra RK (1983) Effects of Temperature on the In vivo Assay of Nitrate Reductase in some $\mathrm{C}_{3}$ and

Cleland EE, Chuine I, Menzel A, Mooney HA, Schwartz MD (2007) Shifting plant phenology in response to global change. Trends Ecol Evol. 22:357-365.

347 Gebauer G, Hahn G, Rodenkirchen H, Zuleger M (1998) Effects of acid irrigation and liming on nitrate reduction and nitrate content of Picea abies (L.) Karst. and Oxalis acetosella L. Plant Soil. 199:59-70.

Gebauer G, Melzer A, Rehder H (1984) Nitrate content and nitrate reductase activity in Rumex obtusifolius: 1. Differences in organs and diurnal changes. Oecologia. 63:136-142.

Gebauer G, Rehder H, Wollenweber B (1988) Nitrate, nitrate reduction and organic nitrogen in

Gebauer G, Schuhmacher MI, Krstic B, Rehder H, Ziegler H (1987) Biomass production and nitrate metabolism of Atriplex hortensis $\mathrm{L} .\left(\mathrm{C}_{3}\right.$ plant $)$ and Amaranthus retroflexus $\mathrm{L} .\left(\mathrm{C}_{4}\right.$ plant $)$ in

358 Gebauer G, Schulze E -D, (1997) Nitrate nutrition of Central European forest trees. In: 
361 Harris D (2007) Quality assurance and calibration methods: Standard addition. In: Harris D (eds)

Quantitative Chemical Analysis. W. H. Freeman and Company, New York, pp 87-90.

363 Hayashi-Tang, M., S. Porder and G.M. Lovett. (2012) Species differences in nitrate reductase activity are unaffected by nitrogen enrichment in northeastern US forests. Forest Ecol Manag. 275:52-59.

Högberg P, Granström A, Johansson T, Lundmark-Thelin A, Näsholm T (1986) Plant nitrate reductase activity as an indicator of availability of nitrate in forest soils. Can J Forest Res. 16:1165-1169.

Högberg P, Högbom L, Näsholm T (1992) Shoot nitrate reductase activities of field-layer species in different forest types. II. Seasonal variation and effects of temperature. Scand J Forest Res. $7: 1-14$

Jaworski EG (1971) Nitrate reductase assay in intact plant tissues. Biochem Bioph Res Co. 43:1274-1279.

374 Keeney DR, Nelson DW (1982) Nitrogen - Inorganic forms. In: Page AL, Miller RH, Keeney DR (eds) Methods of Soil Analysis Part 2. ASA and SSSA, Madison, WI, pp 643-698.

376 Kielland K (2001) Short-circuiting the nitrogen cycle: Strategies of nitrogen uptake in plants from marginal ecosystems. In: Ae N, Arihara J, Okada K and Srinivasan A (eds) Plant Nutrient Acquisition: New Persectives. Springer-Verlag, Berlin. pp 376-398.

379 Kielland K, McFarland J, Olson K (2006a) Amino acid uptake in deciduous and coniferous taiga ecosystems. Plant Soil. 288:297-307.

381 Kielland K, Olson K, Ruess RW, Boone RD (2006b) Contribution of winter processes to soil nitrogen flux in taiga forest ecosystems. Biogeochemistry. 81:349-360.

383 Koyama L, Kielland K (2011) Plant physiological responses to hydrologically mediated changes in nitrogen supply on a boreal forest floodplain: a mechanism explaining the discrepancy in nitrogen demand and supply. Plant Soil. 342:129-139.

386 Koyama L, Tokuchi N, Fukushima K, Terai M, Yamamoto Y (2008) Seasonal changes in nitrate use by three woody species: the importance of the leaf-expansion period. Trees. 22:851-859. 

255-320.

Lillo C, Meyer C, Lea U, Provan F, Oltedal S (2004) Mechanism and importance of post-translational regulation of nitrate reductase. J Exp Bot. 55:1275-1282.

Lisuzzo NJ, Kielland K, Jones JB (2008) Hydrologic controls on nitrogen availability in a high-latitude, semi-arid floodplain. Ecoscience. 15:366-376.

Makoto K, Kajimoto T, Koyama L, Kudo G, Shibata H, Yanai Y, Cornelissen JHC (2014) Winter climate change in plant-soil systems: summary of recent findings and future perspectives. Ecol Res. 29:593-606.

Miller-Rushing AJ, Primack RB (2008) Global warming and flowering times in Thoreau's Concord: a community perspective. Ecology. 89:332-341.

Miyazawa Y, Kikuzawa K (2004) Winter photosynthesis by saplings of evergreen broad-leaved trees in a deciduous temperate forest. New Phytol. 165:857-866.

Nicholas JC, Harper JE, Hageman RH (1976) Nitrate Reductase Activity in Soybeans (Glycine max [L.] Merr.): I. Effects of Light and Temperature. Plant Physiol. 58:731-735.

Ohlson M, Högbom L (1993) Species-specific dynamics in nitrate reductase activity in coexisting swamp forest plants. J Ecol. 81:739-744.

Pearson J, Ji YM (1994) Seasonal variation of leaf glutamine synthetase isoforms in temperate deciduous trees strongly suggests different functions for the enzymes. Plant Cell Environ.

412 Persson J, Nasholm T (2001) Amino acid uptake: a widespread ability among boreal forest plants. Ecol Lett. 4:434-438.

414 Peuke AD, Tischner R (1991) Nitrate uptake and reduction of aseptically cultivated spruce seedlings, 415 Picea abies (L.) karst. J Exp Bot. 42:723-728. 
416 Polgar CA, Primack RB (2011) Leaf-out phenology of temperate woody plants: from trees to

417 ecosystems. New Phytol. 191:926-941.

418 Saarinen T, Rasmus S, Lundell R, Kauppinen O-K, Hänninen H (2016) Photosynthetic and

419 phenological responses of dwarf shrubs to the depth and properties of snow. OIKOS.

$420 \quad 125: 364-373$.

421 Sanders-DeMott R, Templer PH (2017) What about winter? Integrating the missing season into climate change experiments in seasonally snow covered ecosystems. Methods in Ecology

424 Schmidt B, Strack D, Weidner M (1991) Nitrate reductase in needles, roots and trunk wood of spruce trees (Picea abies (L.) Karst.). Trees. 5:215-226.

426 Silla F, Escudero A (2003) Uptake, demand and internal cycling of nitrogen in saplings of Mediterranean Quercus species. Oecologia. 136:28-36.

Smirnoff N, Todd P, Stewart G (1984) The occurrence of nitrate reduction in the leaves of woody plants. Ann Bot. 54:363-374.

430 Stadler J, Gebauer G (1992) Nitrate reduction and nitrate content in ash trees (Fraxinus excelsior L.): distribution between compartments, site comparison and seasonal variation. Trees. 6:236-240.

Sym GJ (1984) Optimisation of the in-vivo Assay Conditions for Nitrate Reductase in Barley

435 Thomas FM, Hilker C (2000) Nitrate reduction in leaves and roots of young pedunculate oaks 436 (Quercus robur) growing on different nitrate concentrations. Environ Exp Bot. 43:19-32.

437 Troelstra SR, Wagenaar R, Smant W, De-Boer W (1995) Soil nitrogen transformations and nitrate 438 utilization by Deschampsia flexuosa (L.) Trin. at two contrasting heathland sites. Plant Soil. 176:81-93.

440 Ueda M, Mizumachi E, Tokuchi N (2010) Winter nitrate uptake by the temperate deciduous tree 441 Quercus serrata. Journal of Forest Research. 15:411-414.

442 Valentine DW, Kielland K, Chapin III FS, McGuire AD, Van Cleve K (2006) Patterns of 443 Biogeochemistry in Alaskan Boreal Forests. In: Chapin III FS, Oswood MW, van Cleve K, 
Viereck LA, Verbyla DL (eds) Alaska's changing boreal forest. Oxford University Press, Inc,

$445 \quad$ New York, pp 241-266.

446 Van Cleve, Keith; Chapin, F. Stuart; Ruess, Roger W. 2017. Bonanza Creek LTER: Hourly Air

447 Temperature Measurements (sample, min, max) at $50 \mathrm{~cm}$ and $150 \mathrm{~cm}$ from 1988 to Present

448 in the Bonanza Creek Experimental Forest near Fairbanks, Alaska, Bonanza Creek LTER -

449 University of Alaska Fairbanks. BNZ:1, http://www.lter.uaf.edu/data/data-detail/id/1.

450 doi:10.6073/pasta/006bae44c88f7d8b6fabe8cfebee86ff, the last accessed date: 2017-03-08

451 Walther G-R, Post E, Convey P, Menzel A, Parmesan C, Beebee T, Fromentin J-M,

452 Hoegh-Guldberg O, Bairlein F (2002) Ecological responses to recent climate change. Nature.

$453 \quad 416: 389-395$.

454 Yao B, Cao J, Zhao C, Rengel Z (2011) Influence of ammonium and nitrate supply on growth,

455 nitrate reductase activity and $\mathrm{N}$-use efficiency in a natural hybrid pine and its parents. J Plant

$456 \quad$ Ecol. 4:275-282.

457 Yarie J, Van Cleve K (2006) Controls over Forest Production in Interior Alaska. In: Chapin III FS,

458 Oswood MW, van Cleve K, Viereck LA, Verbyla DL (eds) Alaska's changing boreal forest.

459 Oxford University Press, Inc, New York, pp 171-188.

460 


\section{FIGURE CAPTIONS}

462

463 Figure 1: Temperature changes in 2009, 2015, and 2016. The temperatures recorded at an adjacent

464 long-term ecological research (LTER) site $\left(64^{\circ} 44^{\prime} 30^{\prime \prime} \mathrm{N}, 148^{\circ} 18^{\prime} 50^{\prime \prime} \mathrm{W}\right)$ are presented as daily means

465 (closed circles: 2009, open circles: 2015, open squares: 2016) and ranges (continuous bars: 2009,

466 dashed bars: 2015, dotted bars: 2016). Arrows indicate the sampling days (closed arrows: 2009,

467 open arrows: summer 2015 and winter 2016). Data were obtained from the Bonanza Creek LTER

468 Database.

469

470 Figure 2: Seasonal differences in nitrate reductase activities (NRA) and $\mathrm{NO}_{3}{ }^{-}-\mathrm{N}$ concentration in

471 current year needles and fine roots of black spruce (P. mariana) in two sites. (a) NRA $\left(+\mathrm{NO}_{3}\right)$

472 assayed with incubation buffer containing $\mathrm{NO}_{3}{ }^{-} \mathrm{N}$, (b) $\mathrm{NRA}\left(-\mathrm{NO}_{3}\right)$ assayed with incubation buffer

473 containing no $\mathrm{NO}_{3}{ }^{-}-\mathrm{N}$, and (c) $\mathrm{NO}_{3}{ }^{-}-\mathrm{N}$ concentration. Both NRA measurements were made at $30{ }^{\circ} \mathrm{C}$.

474 Samples were collected from five individual trees in each site.

475

476 Figure 3: The effects of incubation temperature on NRA in current year needles and fine roots of

477 black spruce (P. mariana) collected in December 2009 and (a) supplied with $\mathrm{NO}_{3}{ }^{-} \mathrm{-N}\left[\mathrm{NRA}\left(+\mathrm{NO}_{3}\right)\right]$,

478 or (b) not supplied with $\mathrm{NO}_{3}^{-}-\mathrm{N}\left[\mathrm{NRA}\left(-\mathrm{NO}_{3}\right)\right]$. Samples were collected from five individual trees in 479 site 1. 


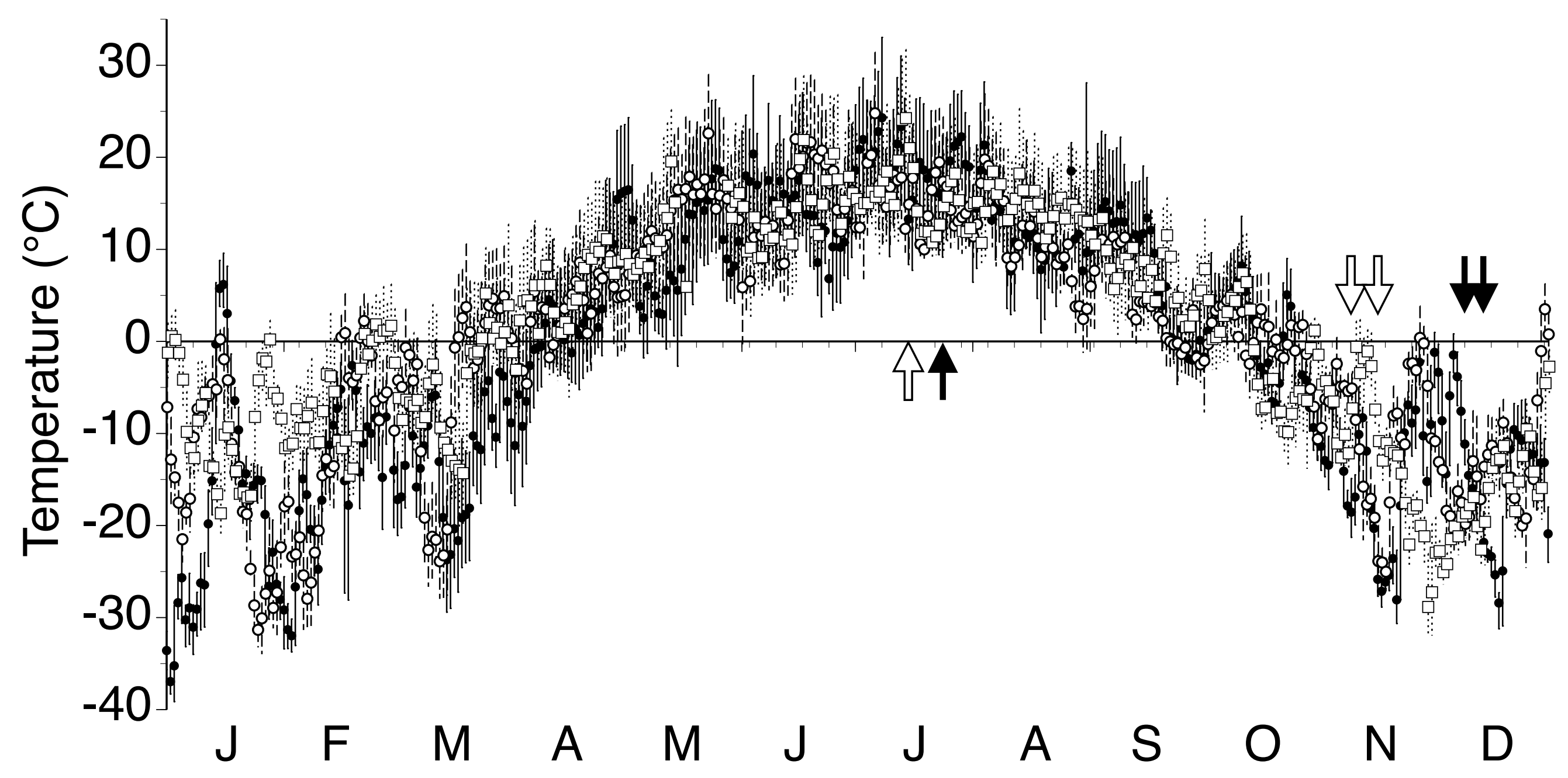

Fig. 1 
(a)

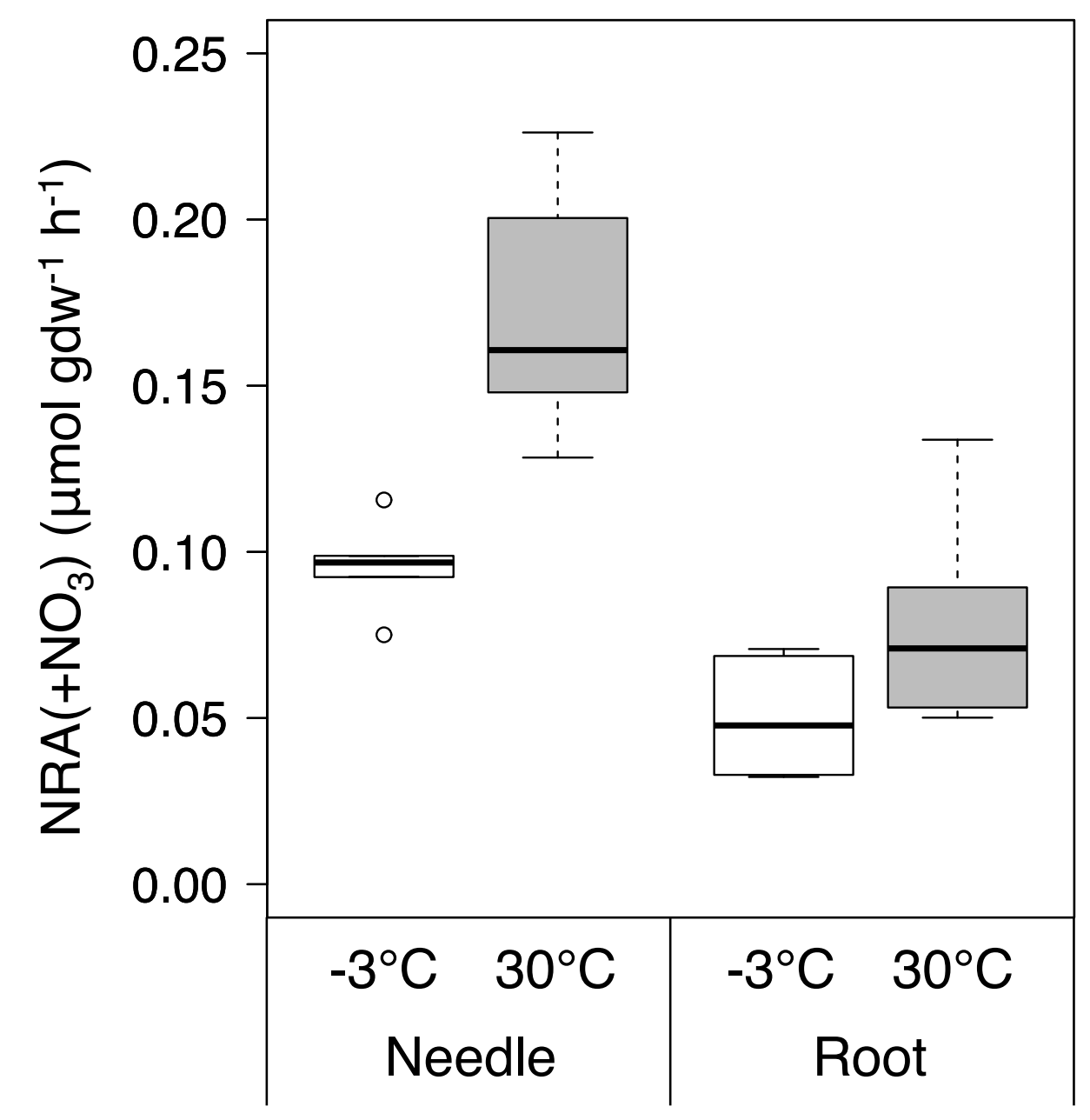

(b)

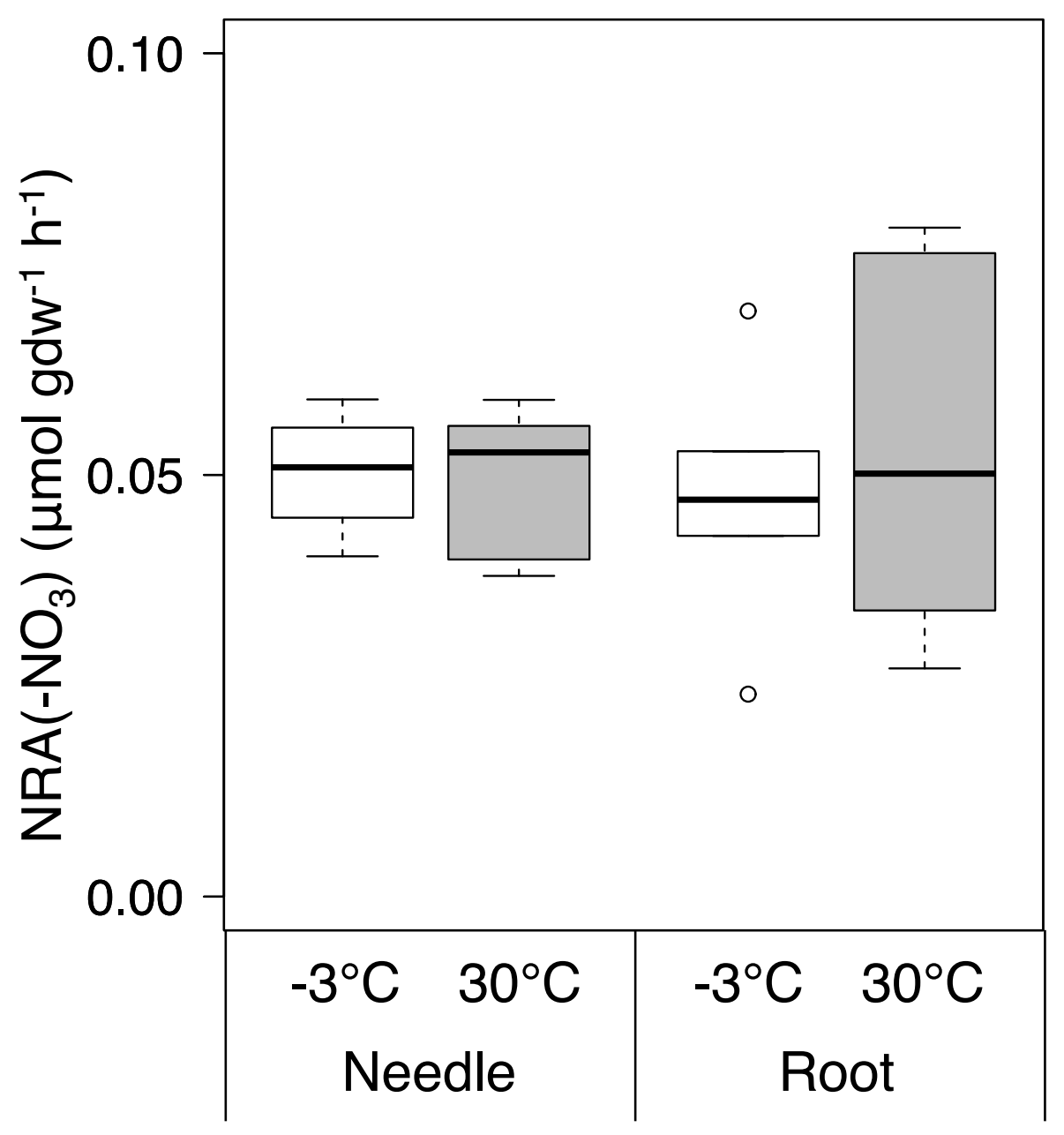

Fig. 3 
Table 1 Explanatory variables and the coefficients of variables for the generalized linear mixed model (GLMM) to describe the effects of season, site, and tissue on $\mathrm{NRA}(+\mathrm{NO} 3), \mathrm{NRA}(-\mathrm{NO} 3)$ and $\mathrm{NO}_{3}{ }^{-}-\mathrm{N}$ concentration in black spruce. The coefficients for the best performing models are shown, and the models were selected to have the lowest Akaike Information Criterion (AIC) by comparing AIC for each of possible subset of explanatory variables (See Appendices 2-4 for details). P values indicate the probability of including zero value of coefficients within $95 \%$ Wald confidence interval.

\begin{tabular}{|c|c|c|c|c|c|c|c|c|c|c|}
\hline & \multirow{2}{*}{ Variable type } & \multicolumn{3}{|c|}{$\mathrm{NRA}\left(+\mathrm{NO}_{3}\right)$} & \multicolumn{3}{|c|}{$\mathrm{NRA}\left(-\mathrm{NO}_{3}\right)$} & \multicolumn{3}{|c|}{$\mathrm{NO}_{3}^{-}-\mathrm{N}$ concentration } \\
\hline & & Coefficient & Std Error & $\mathrm{P}$ value & Coefficient & Std Error & $\mathrm{P}$ value & Coefficient & Std Error & $P$ value \\
\hline (Intercept) & & 12.94 & 5.24 & 0.014 & 23.17 & 4.51 & $<0.001$ & 285.20 & 93.70 & 0.002 \\
\hline Season $^{\dagger}$ & categorical & -5.01 & 6.15 & 0.415 & -0.29 & 6.09 & 0.962 & -38.84 & 127.45 & 0.761 \\
\hline Site $^{\dagger \dagger}$ & categorical & 78.78 & 37.17 & 0.034 & 53.52 & 7.14 & $<0.001$ & & - & \\
\hline Tissue $^{\dagger \dagger \dagger}$ & categorical & & $--^{\dagger \dagger \dagger}$ & & -6.55 & 2.35 & 0.005 & -7.16 & 134.99 & 0.958 \\
\hline Season $\times$ Site & interaction & -68.30 & 38.04 & 0.073 & -23.85 & 8.20 & 0.004 & & - & \\
\hline Site $\times$ Tissue & interaction & & - & & -29.38 & 4.82 & $<0.001$ & & - & \\
\hline Season $\times$ Tissue & interaction & & - & & 4.95 & 3.33 & 0.137 & 1139.10 & 572.22 & 0.047 \\
\hline Season $\times$ Site $\times$ Tissue & interaction & & - & & & - & & & - & \\
\hline
\end{tabular}

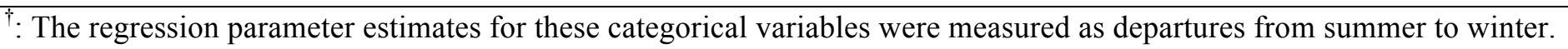

$\dagger$ : The regression parameter estimates for these categorical variables were measured as departures from site 1 to site 2 .

$\stackrel{+1 \dagger}{\circ}$ The regression parameter estimates for these categorical variables were measured as departures from current year needles to fine roots.

†T: Variables with blank (-) in coefficients were not used in the selected best performing model based on AIC. 
Table 2 Explanatory variables and the coefficients of variables for the generalized linear mixed model (GLMM) to describe the effects of incubation temperature and tissue on $\mathrm{NRA}\left(+\mathrm{NO}_{3}\right)$ and $\mathrm{NRA}\left(-\mathrm{NO}_{3}\right)$ in black spruce. The coefficients for the best performing models are shown, and the models were selected to have the lowest Akaike Information Criterion (AIC) by comparing AIC for each of possible subset of explanatory variables (See Appendices 56 for details). P values indicate the probability of including zero value of coefficients within $95 \%$ Wald confidence interval.

\begin{tabular}{|c|c|c|c|c|c|c|c|}
\hline & \multirow{2}{*}{ Variable type } & \multicolumn{3}{|c|}{$\mathrm{NRA}\left(+\mathrm{NO}_{3}\right)$} & \multicolumn{3}{|c|}{$\mathrm{NRA}\left(-\mathrm{NO}_{3}\right)$} \\
\hline & & Coefficient & Std Error & $\mathrm{P}$ value & Coefficient & Std Error & $P$ value \\
\hline (Intercept) & & 10.98 & 1.28 & $<0.001$ & 21.80 & 2.50 & $<0.001$ \\
\hline Incubation temperature $^{\dagger}$ & categorical & -5.04 & 1.53 & 0.001 & -0.26 & 1.76 & 0.883 \\
\hline Tissue $^{\dagger \dagger}$ & categorical & 7.45 & 1.36 & $<0.001$ & & - & \\
\hline Incubation temperature $\times$ Tissue & interaction & & $-{ }_{-1 \dagger}^{\dagger \dagger}$ & & & - & \\
\hline
\end{tabular}

${ }^{\dagger}$ : The regression parameter estimates for these categorical variables were measured as departures from the incubation temperature $-3{ }^{\circ} \mathrm{C}$ and $30{ }^{\circ} \mathrm{C}$.

${ }^{\dagger}$ : The regression parameter estimates for these categorical variables were measured as departures from current year needles to fine roots.

${ }^{\dagger \dagger}$ : Variables with blank (-) in coefficients were not used in the selected best performing model based on AIC. 
Appendix 1: Effects of $\mathrm{NO}_{3}{ }^{-}-\mathrm{N}$ concentration in incubation buffer on needle NRA of black spruce ( $P$. mariana). The incubation buffers had same composition other than $\mathrm{NO}_{3}{ }^{-} \mathrm{N}$ concentration. Different symbols indicate different individual trees $(\mathrm{n}=3)$.

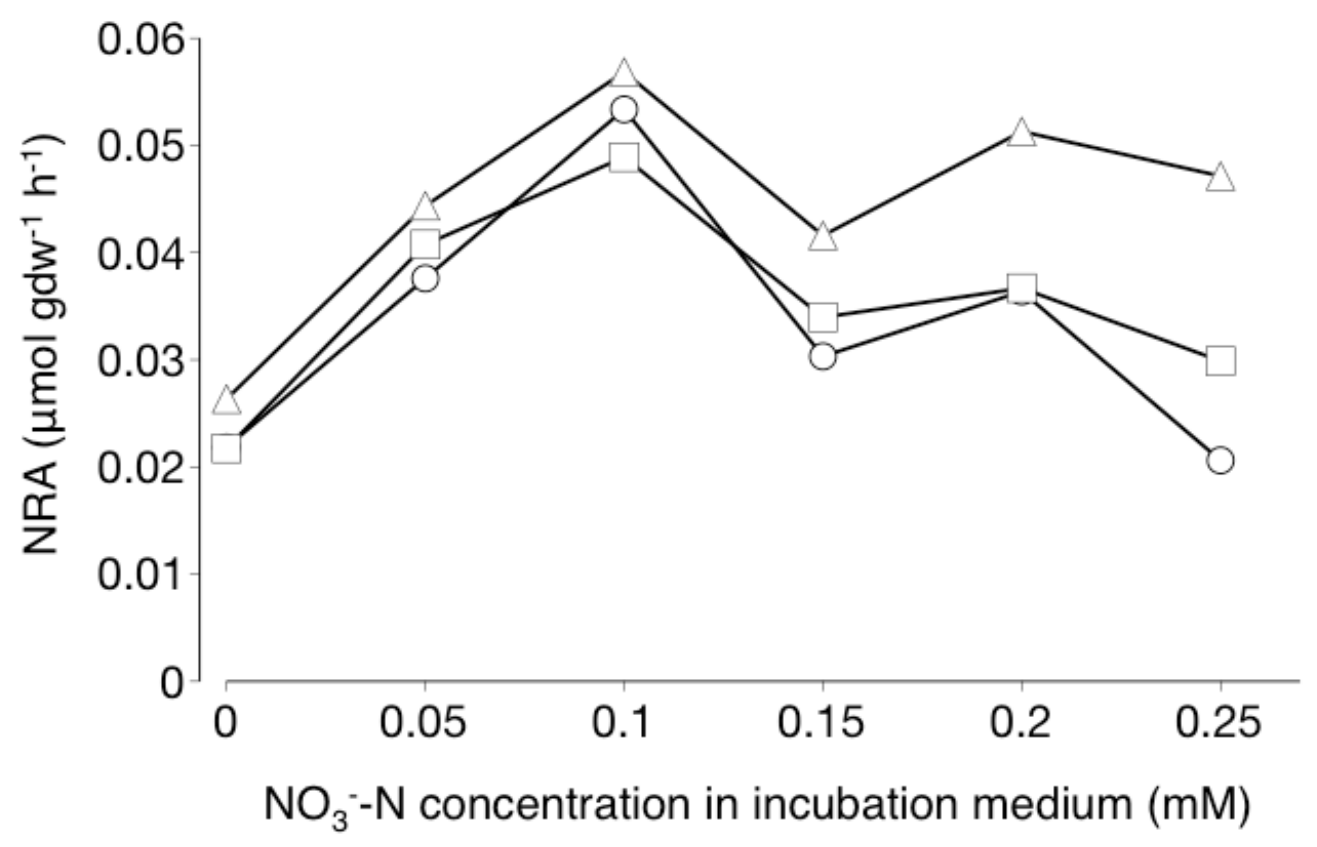


Appendix 2 Comparison of candidate generalized linear mixed models (GLMM) to test the effects of season, site, tissue, and their interactions on $\mathrm{NRA}\left(+\mathrm{NO}_{3}\right)$ of black spruce. The variables (fixed effects) and their interactions applied in each model are indicated by “+”, and the models are rank ordered from most to least supported based on AIC.

\begin{tabular}{|c|c|c|c|c|c|c|c|c|c|}
\hline Season & Site & Tissue & Season $\times$ Site & Site $\times$ Tissue & Tissue $\times$ Season & Season $\times$ Site $\times$ Tissue & $\mathrm{df}$ & AIC & $\triangle \mathrm{AIC}$ \\
\hline+ & + & & + & & & & 34 & -155.33 & \\
\hline+ & + & + & + & & & & 33 & -154.15 & 1.18 \\
\hline+ & + & + & + & + & & & 32 & -152.80 & 1.35 \\
\hline+ & + & & & & & & 35 & -152.17 & 0.63 \\
\hline \multirow[t]{2}{*}{+} & + & + & + & & + & & 32 & -152.15 & 0.02 \\
\hline & + & & & & & & 36 & -151.94 & 0.20 \\
\hline+ & + & + & & & & & 34 & -150.89 & 1.06 \\
\hline \multirow[t]{2}{*}{+} & + & + & + & + & + & & 31 & -150.81 & 0.08 \\
\hline & + & + & & & & & 35 & -150.74 & 0.07 \\
\hline \multirow[t]{2}{*}{+} & + & + & & + & & & 33 & -149.48 & 1.26 \\
\hline & + & + & & + & & & 34 & -149.37 & 0.11 \\
\hline+ & + & + & + & + & + & + & 30 & -149.33 & 0.04 \\
\hline+ & + & + & & & + & & 33 & -148.94 & 0.38 \\
\hline+ & & & & & & & 36 & -148.14 & 0.80 \\
\hline+ & + & + & & + & + & & 32 & -147.59 & 0.55 \\
\hline \multirow[t]{2}{*}{+} & & + & & & & & 35 & -146.99 & 0.61 \\
\hline & & + & & & & & 36 & -146.55 & 0.44 \\
\hline+ & & + & & & + & & 34 & -145.02 & 1.52 \\
\hline
\end{tabular}


Appendix 3 Comparison of candidate generalized linear mixed models (GLMM) to test the effects of season, site, tissue, and their interactions on $\operatorname{NRA}\left(-\mathrm{NO}_{3}\right)$ of black spruce. The variables (fixed effects) and their interactions applied in each model are indicated by “+”, and the models are rank ordered from most to least supported based on AIC.

\begin{tabular}{|c|c|c|c|c|c|c|c|c|c|}
\hline Season & Site & Tissue & Season $\times$ Site & Site $\times$ Tissue & Tissue $\times$ Season & Season $\times$ Site $\times$ Tissue & $\mathrm{df}$ & AIC & $\triangle \mathrm{AIC}$ \\
\hline+ & + & + & + & + & + & & 31 & -239.95 & \\
\hline+ & + & + & + & + & & & 32 & -239.82 & 0.13 \\
\hline+ & + & + & + & + & + & + & 30 & -237.96 & 1.86 \\
\hline+ & + & + & & + & + & & 32 & -236.32 & 1.65 \\
\hline \multirow[t]{2}{*}{+} & + & + & & + & & & 33 & -236.31 & 0.01 \\
\hline & + & + & & + & & & 34 & -235.32 & 0.99 \\
\hline+ & + & + & + & & & & 33 & -217.90 & 17.42 \\
\hline+ & + & + & + & & + & & 32 & -215.90 & 2.00 \\
\hline \multirow[t]{2}{*}{+} & + & + & & & & & 34 & -212.09 & 3.81 \\
\hline & + & + & & & & & 35 & -211.70 & 0.39 \\
\hline+ & + & + & & & + & & 33 & -210.10 & 1.59 \\
\hline \multirow[t]{2}{*}{+} & + & & + & & & & 34 & -208.12 & 1.98 \\
\hline & & + & & & & & 36 & -206.09 & 2.03 \\
\hline+ & & + & & & & & 35 & -205.50 & 0.59 \\
\hline \multirow[t]{2}{*}{+} & & + & & & + & & 34 & -203.51 & 1.99 \\
\hline & + & & & & & & 36 & -202.83 & 0.69 \\
\hline+ & + & & & & & & 35 & -202.27 & 0.56 \\
\hline+ & & & & & & & 36 & -195.16 & 7.11 \\
\hline
\end{tabular}


Appendix 4 Comparison of candidate generalized linear mixed models (GLMM) to test the effects of season, site, tissue, and their interactions on $\mathrm{NO}_{3}{ }^{-}-\mathrm{N}$ concentration of black spruce. The variables (fixed effects) and their interactions applied in each model are indicated by "+", and the models are rank ordered from the most to least supported based on AIC.

\begin{tabular}{|c|c|c|c|c|c|c|c|c|c|}
\hline Season & Site & Tissue & Season $\times$ Site & Site $\times$ Tissue & Tissue $\times$ Season & Season $\times$ Site $\times$ Tissue & $\mathrm{df}$ & AIC & $\triangle \mathrm{AIC}$ \\
\hline \multirow[t]{2}{*}{+} & & + & & & + & & 33 & -388.70 & \\
\hline & & + & & & & & 35 & -387.25 & 1.45 \\
\hline \multirow[t]{2}{*}{+} & + & + & & & + & & 32 & -387.24 & 0.01 \\
\hline & + & & & & & & 35 & -386.70 & 0.54 \\
\hline+ & & & & & & & 35 & -386.58 & 0.12 \\
\hline \multirow[t]{2}{*}{+} & + & + & & + & + & & 31 & -386.28 & 0.31 \\
\hline & + & + & & & & & 34 & -385.88 & 0.39 \\
\hline+ & & + & & & & & 34 & -385.86 & 0.03 \\
\hline+ & + & + & + & & + & & 31 & -385.25 & 0.61 \\
\hline \multirow[t]{2}{*}{+} & + & & & & & & 34 & -385.24 & 0.01 \\
\hline & + & + & & + & & & 33 & -384.67 & 0.57 \\
\hline+ & + & + & + & + & + & & 30 & -384.58 & 0.09 \\
\hline+ & + & + & & & & & 33 & -384.46 & 0.12 \\
\hline+ & + & + & + & + & + & + & 29 & -383.60 & 0.86 \\
\hline+ & + & & + & & & & 33 & -383.35 & 0.25 \\
\hline+ & + & + & & + & & & 32 & -383.25 & 0.10 \\
\hline+ & + & + & + & & & & 32 & -382.56 & 0.70 \\
\hline+ & + & + & + & + & & & 31 & -381.37 & 1.18 \\
\hline
\end{tabular}


Appendix 5 Summary of generalized linear mixed models (GLMM) comparisons to test the effects of incubation temperature, tissue, and their interactions on $\mathrm{NRA}\left(+\mathrm{NO}_{3}\right)$ of black spruce. Models are rank ordered from the most to least supported based on AIC.

\begin{tabular}{cccccc}
\hline Incubation temperature & Tissue & $\begin{array}{c}\text { Incubation temperature } \\
\times \text { Tissue }\end{array}$ & df & AIC & sAIC \\
\hline+ & + & & 15 & -80.40 & \\
+ & + & + & 14 & -79.21 & 0.23 \\
& + & & 16 & -76.17 & 0.05 \\
+ & & & 16 & -62.37 & 1.45 \\
\hline
\end{tabular}


Appendix 6 Summary of generalized linear mixed models (GLMM) comparisons to test the effects of incubation temperature, tissue, and their interactions on NRA(- $\left.\mathrm{NO}_{3}\right)$ of black spruce. Models are rank ordered from the most to least supported based on AIC.

\begin{tabular}{ccccccc}
\hline Incubation temperature & Tissue & $\begin{array}{c}\text { Incubation temperature } \\
\times \text { Tissue }\end{array}$ & df & AIC & \multicolumn{2}{c}{$\Delta$ AIC } \\
\hline & + & & 16 & -109.62 & \\
+ & & & 16 & -109.61 & 0.01 \\
+ & + & & 15 & -107.63 & 1.98 \\
+ & + & + & 14 & -106.25 & 1.38 \\
\hline
\end{tabular}

